\title{
Leukocytosis, muscle damage and increased lymphocyte proliferative response after an adventure sprint race
}

\author{
R. Tossige-Gomes ${ }^{1}$, V.O. Ottone ${ }^{1}$, P.N. Oliveira ${ }^{2}$, D.J.S. Viana ${ }^{2}$, T.L. Araújo ${ }^{1}$ \\ F.J. Gripp ${ }^{2}$ and E. Rocha-Vieira ${ }^{3,4}$ \\ ${ }^{1}$ Departamento de Fisioterapia, Faculdade de Ciências Biológicas e da Saúde, \\ Universidade Federal dos Vales do Jequitinhonha e Mucuri, Diamantina, MG, Brasil \\ ${ }^{2}$ Departamento de Educação Física, Faculdade de Ciências Biológicas e da Saúde, \\ Universidade Federal dos Vales do Jequitinhonha e Mucuri, Diamantina, MG, Brasil \\ ${ }^{3}$ Programa Multicêntrico de Pós-Graduação em Ciências Fisiológicas, \\ Universidade Federal dos Vales do Jequitinhonha e Mucuri, Diamantina, MG, Brasil \\ ${ }^{4}$ Departamento de Ciências Básicas, Faculdade de Ciências Biológicas e da Saúde, \\ Universidade Federal dos Vales do Jequitinhonha e Mucuri, Diamantina, MG, Brasil
}

\begin{abstract}
The effect of an adventure sprint race (ASR) on T-cell proliferation, leukocyte count and muscle damage was evaluated. Seven young male runners completed an ASR in the region of Serra do Espinhaço, Brazil. The race induced a strong leukocytosis $\left(6.22 \pm 2.04 \times 10^{3}\right.$ cells $/ \mathrm{mm}^{3}$ before vs $14.81 \pm 3.53 \times 10^{3}$ cells $/ \mathrm{mm}^{3}$ after the race), marked by a significant increase of neutrophils and monocytes $(\mathrm{P}<0.05)$, but not total lymphocytes, $\mathrm{CD} 3^{+} \mathrm{CD} 4^{+}$or $\mathrm{CD} 3^{+} \mathrm{CD} 8^{+}$cells. However, the $\mathrm{T}$-cell proliferative response to mitogenic stimulation was increased $(P=0.025)$ after the race, which contradicted our hypothesis that ASR, as a high-demand competition, would inhibit T-cell proliferation. A positive correlation $(P=0.03, r=0.79)$ was observed between the proliferative response of lymphocytes after the race and the time to complete the race, suggesting that the proliferative response was dependent on exercise intensity. Muscle damage was evident after the race by increased serum levels of aspartate amino transferase $(24.99 \pm 8.30$ vs $50.61 \pm 15.76 \mathrm{U} / \mathrm{L}, \mathrm{P}=0.003)$. The results suggest that humoral factors and substances released by damaged muscle may be responsible for lymphocyte activation, which may be involved in muscle recovery and repair.
\end{abstract}

Key words: Strenuous exercise; Lymphocyte; Proliferation; Aspartate amino transferase; Immunosuppression

\section{Introduction}

Strenuous endurance exercise can induce a variety of modifications in several physiological systems. It is well recognized that strenuous exercise is marked by an acute inflammatory response, characterized by leukocytosis and leukocyte activation, release of inflammatory mediators and tissue damage (1-3). Muscle damage and/or altered muscle cell permeability lead to cellular protein leakage, and increased serum activity of many enzymes. These include creatine kinase, lactate dehydrogenase and aspartate amino transferase (AST), which have been used as biochemical indicators of exercise-induced tissue damage (4).

Strenuous exercise is commonly associated with increased symptoms of upper respiratory tract infection in athletes (5-7), suggesting that high-volume exercise may have an immunosuppressive effect, as indicated by the suppression of lymphocyte proliferation, neutrophil phagocytosis and microbicidal activity (7), as well as increased lymphocyte and neutrophil apoptosis (8). The immunological mechanisms that underlie this apparent increase in infection susceptibility in athletes are unknown, but are likely to be multi-factorial and include perturbations of the T-cell compartment. The proliferative capacity of lymphocytes is a key event in the adaptive immune response, and the host capacity to respond to an immunological challenge can be significantly compromised if lymphocyte proliferation is not adequate.

Correspondence: E. Rocha-Vieira, Laboratório de Biologia Celular e Molecular, CIPq-Saúde, Universidade Federal dos Vales do Jequitinhonha e Mucuri, Campus JK, Rodovia MGT367, km 583, 5000, 39100-000 Diamantina, MG, Brasil. Fax: +55-3138-35321200. E-mail: etelvieira@terra.com.br 
Adventure racing is a fast growing ultra-endurance sport, during which participants are required to perform multiple disciplines that require considerable skill and physical capacity $(9,10)$. The competition is physically demanding, and because the aim is to reach as many checkpoints as possible within a given time interval, competitors must cover large distances as quickly as possible. Adventure racing includes sprints $(<6 \mathrm{~h})$, intermediate (6-12 h), long (12-36 h), and expedition races (>36 h).

Despite its growing popularity, data on the effects of adventure sprint races (ASRs) on immune responsiveness and exercise-induced inflammatory responses are scarce. Additional data would be useful for understanding and management of the physiological response to competition. Recent reports on the effects of adventure racing on lymphocyte and neutrophil viability have been reported (11), and showed no changes in neutrophil phagocytic capacity after the race despite increased neutrophil death by necrosis and lymphocyte apoptosis. Although increased lymphocyte apoptosis can potentially be involved in exercise immunosuppression, lymphocyte function, i.e., proliferative response, was not evaluated by Levada-Pires et al. (11). Thus, the impact of this kind of competition on immune responsiveness has not been fully investigated. In this context, the present research evaluated the effect of ASR on mitogen-induced proliferative response of lymphocytes, leukocytosis and muscle damage. We hypothesized that, since ASR is a strenuous competition, it could result in leukocytosis, muscle damage and reduced lymphocyte proliferative response.

\section{Material and Methods}

\section{Subjects and race description}

The present study enrolled 8 male nonsmoking athletes $(27.7 \pm 5.9$ years). These volunteers did not report any infectious or autoimmune diseases and were not taking any anti-inflammatory drugs. All were amateur cyclists who regularly participated in state and national competitions, but had little or no prior experience in adventure races. They participated as individual competitors in an adventure sprint race in the Serra do Espinhaço region, Diamantina, MG, Brazil (-18 $18^{\circ} 58^{\prime \prime}$ $\mathrm{S},-43^{\circ} 39^{\prime}$ 02" W) in October 2010. The competition included $12 \mathrm{~km}$ of trekking, $100 \mathrm{~m}$ of vertical techniques, and $30 \mathrm{~km}$ of mountain biking, covering a total distance of $42.1 \mathrm{~km}$. Serra do Espinhaço is a rugged region of cerrado vegetation, with elevations of 665-1143 m. During the competition the recorded temperature was $20.8 \pm 4.3^{\circ} \mathrm{C}$ with a relative humidity of $49.9 \pm 18.9 \%$. Nutritional and hydration strategies were the responsibility of each competitor; race organizers provided nutrition and hydration stops for the competitors.

The Internal Review Board of the Universidade
Federal dos Vales do Jequitinhonha e Mucuri approved the study. All volunteers signed an informed consent form, thereby agreeing to participate in the study.

\section{Precompetition evaluation}

Five days before the race, resting and maximum heart rate, body mass, percentage of body fat, and peak oxygen consumption $\left(\mathrm{VO}_{2}\right.$ peak $)$ were measured. The Balke cycle ergometer protocol was employed to estimate aerobic capacity $\left(\mathrm{VO}_{2}\right.$ peak $)$. Briefly, the protocol consisted of progressive exercise performed at $50-60 \mathrm{rpm}$, with an initial load of $1.5 \mathrm{~kg}$. The load was increased by $0.5 \mathrm{~kg}$ every 2 min until fatigue. Resting and maximum heart rate were measured using a heart rate monitor (Polar ${ }^{\circledR}$ RS800, USA). Body fat percentage was estimated according to Jackson and Pollock (12), using the tricep, suprailiac and calf skinfolds.

\section{Competition outcomes}

Peripheral venous blood was collected from the antecubital vein $24 \mathrm{~h}$ before and immediately after the race, using heparinized vacuum tubes. The pre-race blood collection was performed $1 \mathrm{~h}$ after breakfast, and volunteers were instructed to have the same breakfast as planned for the day of competition. On race day, volunteers were asked about the breakfast before the beginning of the competition, and all confirmed that they ate the same breakfast as before the pre-race blood collection.

Total and differential leukocyte counts were performed using an automated cell counter (CC550, Celm, Brazil) and blood smears were prepared with Giemsa and MayGrünwald stains.

A blood sample (approximately $1 \mathrm{~mL}$ ) was centrifuged $\left(400 \mathrm{~g}, 15 \mathrm{~min}, 25^{\circ} \mathrm{C}\right.$ ) and the plasma was collected for the measurement of AST and alanine amino transferase (ALT) activities. The measurements of ALT and AST activities were carried out by monitoring the rate of $\mathrm{NADH}$ oxidation in a coupled reaction system employing lactate and malate dehydrogenase, respectively, using commercially available kits (K049 and K048, Bioclin, Brazil) and a semi-automatic analyzer (PW-3000M, Pioway, China). The oxidation of $\mathrm{NADH}$ to $\mathrm{NAD}^{+}$was accompanied by a decrease in absorbance at $340 \mathrm{~nm}$. Under circumstances in which the ALT and AST activities are rate limiting, the rate decrease is directly proportional to the ALT or AST activity in the sample.

The peripheral blood mononuclear cells (PBMC) were isolated from the remaining blood sample by centrifugation $\left(400 \mathrm{~g}, 30 \mathrm{~min}, 25^{\circ} \mathrm{C}\right)$, using Histopaque ${ }^{\mathrm{R}} 1077$ (Sigma, USA), as described by Bicalho et al. (13). A sample of the PBMC $\left(5 \times 10^{5}\right.$ cells $)$ was suspended in phosphate-buffered saline (PBS) and stained with antiCD3, anti-CD4 and anti-CD8 monoclonal antibodies (BD Biosciences, USA), conjugated with specific fluorochromes, to determine the ex vivo percent of TCD4 ${ }^{+}$ 
A

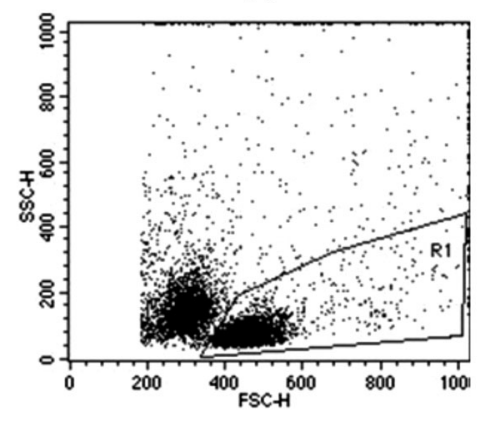

C

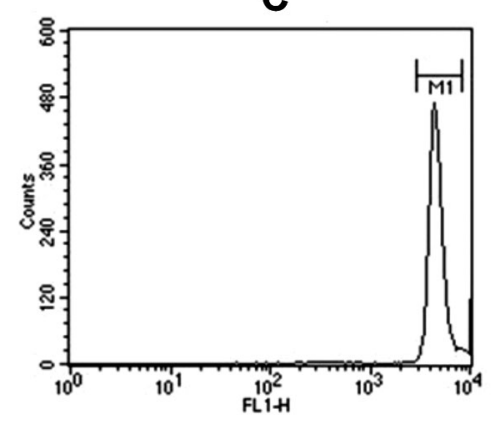

B

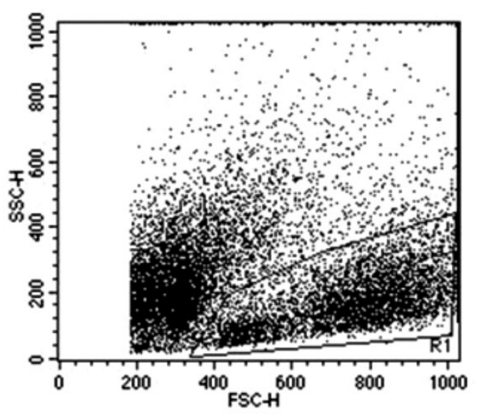

D

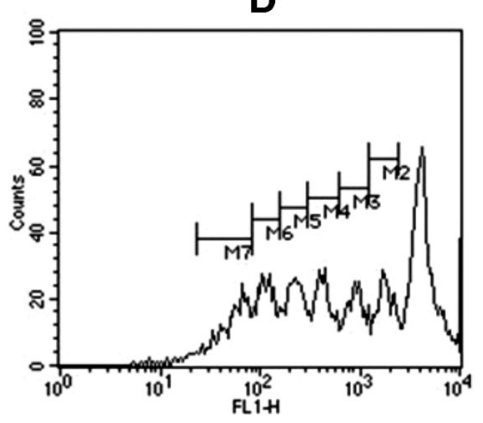

Figure 1. Analysis of cell proliferation using carboxyfluorescein succinimidyl ester (CFSE) by flow cytometry. $A$, Control for unstimulated cultures; $B$, phytohemagglutinin-stimulated cultures; $C$, CFSE-stained cells derived from unstimulated cultures; $D$, CFSE-stained cells in cultures stimulated with PHA. SSC and FSC = side and forward scatter, respectively. and TCD8 ${ }^{+}$cells, as described by Openshaw et al. (14).

The proliferative response of lymphocytes was evaluated by the decay of carboxyfluorescein succinimidyl ester (CFSE) fluorescence as previously described (15). Briefly, PBMC $\left(1 \times 10^{7}\right.$ cells $\left./ \mathrm{mL}\right)$ were suspended in PBS with $0.1 \%$ bovine serum albumin and labeled with $10 \mu \mathrm{M}$ CFSE (Sigma) (16). The cells were washed and suspended in RPMI (Sigma) supplemented with $2 \mathrm{mM}$ L-glutamine (Sigma), antibiotic/antimycotic solution (100 IU $/ \mathrm{mL}$ penicillin G, $100 \mu \mathrm{g} / \mathrm{mL}$ streptomycin and $2.5 \mu \mathrm{g} / \mathrm{mL}$ fungizone; Sigma), and $10 \%$ fetal calf serum (Gibco, USA). Then, PBMC were stimulated with $1 \mu \mathrm{g} / \mathrm{mL}$ mitogen phytohemagglutinin (PHA, Sigma) for 5 days at $37^{\circ} \mathrm{C}$ and $5 \% \mathrm{CO}_{2}$. After the culture period, cells were washed twice in PBS (200 g, $\left.10 \mathrm{~min}, 4^{\circ} \mathrm{C}\right)$, suspended in $\mathrm{PBS} / 2 \%$ paraformaldehyde, for analysis by flow cytometry (FACScan, Becton Dickinson, USA).

Data acquisition was performed using the region of small lymphocytes and blast cells according to the size and granularity profiles [forward (FSC) vs side scatter (SSC)]. CFSE fluorescence was measured in the FL1 channel; 50,000 events in the $\mathrm{R} 1$ region were acquired for later analysis. The acquired data were analyzed using the Cell Quest program (Becton Dickinson).

Regions of analysis were defined as follows. The R1 region was defined in dot plots of $\mathrm{FSC} \times \mathrm{SSC}$ and comprised lymphocytes and blast cells for unstimulated (Figure 1A) and PHA-stimulated cultures (Figure 1B). The events in R1 were then analyzed for CFSE fluorescence in histograms of FL1 (Figure $1 \mathrm{C}$ and $\mathrm{D}$ ). The $\mathrm{M} 1$ region was defined as CFSE-stained cells derived from unstimulated cultures, which represented the peak of quiescent cells (Figure $1 \mathrm{C}$ ). The $\mathrm{M} 2$ to $\mathrm{M} 7$ regions were defined according to the peaks of different CFSE intensities in cultures stimulated with PHA (Figure 1D).

The proliferative index was calculated from the data in the histograms considering that two cells with a given CFSE intensity were produced by mitosis of a single cell, possessing a CFSE intensity immediately above, using the following formula (17): proliferative index $=(100-Y) / Y$, where $\mathrm{Y}(\%)=\mathrm{X} 0+\mathrm{X} 1 / 2+\mathrm{X} 2 / 4+\mathrm{X} 3 / 8+\mathrm{X} 4 / 16+\mathrm{X} 5 / 32+$ $\mathrm{X} 6 / 64+\mathrm{X} 7 / 128, \mathrm{X} 0$ represents the percentage of $\mathrm{T}$ cells that did not divide (located at $M 1$ ), and $X 1-7$ represents the peak of gradual division (located from M2 to M7).

\section{Statistical analysis}

GraphPad Prism version 5.00 for Mac OSX (GraphPad Software, USA, http://www.graphpad.com) was used for the statistical analysis. $P \leq 0.05$ was considered to be statistically significant. Data are reported as means $\pm S D$. The Shapiro-Wilk test was used to evaluate the normalcy of the data. Since the dependent variables were normally distributed/transformed, parametric tests were used for statistical analysis. The Student paired $t$-test was used to compare the total and differential leukocyte count, percentage of TCD4 ${ }^{+}$and TCD8 ${ }^{+}$cells, activity of the enzymes ALT and AST and the proliferative response of $T$ cells before and after the race. Pearson's correlation was used to evaluate the relationship between the biological aspects studied and race duration. 
Table 1. Subject characteristics.

\begin{tabular}{lr}
\hline Characteristics & Means $\pm \mathrm{SD}$ \\
\hline Age (years) & $27.7 \pm 5.9$ \\
Body mass $(\mathrm{kg})$ & $63.2 \pm 3.6$ \\
Height $(\mathrm{cm})$ & $170.2 \pm 3.4$ \\
Body fat $(\%)$ & $6.9 \pm 1.7$ \\
$\mathrm{VO}_{2}$ peak $\left(\mathrm{mL} \mathrm{O} \mathrm{O}_{2} \cdot \mathrm{kg}^{-1} \cdot \mathrm{min}^{-1}\right)$ & $60.8 \pm 1.8$ \\
\hline
\end{tabular}

\section{Results}

One of the 8 athletes initially enrolled in the study did not complete the race because he got lost during the trekking stage and did not finish the race within the time frame. Table 1 describes the mean age, body mass, body fat percentage, height, and $\mathrm{VO}_{2}$ peak of the subjects. The mean race duration was $4 \mathrm{~h} 38 \min 32 \mathrm{~s} \pm 48 \min 12 \mathrm{~s}$. The first athlete finished the race in $3 \mathrm{~h} 54 \mathrm{~min} 57 \mathrm{~s}$ and the last in $6 \mathrm{~h} 7 \mathrm{~min} 52 \mathrm{~s}$.

The race caused significant alterations in leukocyte count profiles (Table 2). A 2.3-fold increase $(P=0.0006)$ in total leukocyte count was observed after the competition, which was due mainly to the increased number of neutrophils $(P<0.0001)$ and monocytes $(P=0.02)$. No effect of the race on the number of circulating lymphocytes was observed $(P=0.7)$. The race did not have an effect on the percentages of $\mathrm{CD}^{+}{ }^{+} \mathrm{CD} 4^{+}$or $\mathrm{CD}^{+}{ }^{+} \mathrm{CD} 8^{+}$ cells (Table 3 ).

However, the lymphocyte proliferative response to stimulation by PHA significantly increased from $1.73 \pm$ 0.96 before the race to $2.66 \pm 1.61$ after the race $(P=$ 0.025). We also evaluated the plasma levels of the enzymes AST and ALT (Figure 2). The plasma levels of AST increased $(P=0.003)$ from $24.99 \pm 8.30$ before to $50.61 \pm 15.76 \mathrm{U} / \mathrm{L}$ after the race. The race had no effect on the ALT levels ( $P=0.06$; Figure $2 B)$.

Considering that leukocytosis, proliferative response and muscle enzyme leakage can be related to exercise intensity we evaluated whether the alterations observed could be related to the time to complete the race. No correlation was observed between AST activity and leukocyte number and the time to finish the race (data not shown). However, a positive correlation $(P=0.03$, $r=0.79, r^{2}=0.63$, Pearson's correlation) was observed
Table 3. Adventure sprint race had no effect on the percentage of $\mathrm{T}$ helper $\left(\mathrm{CD}^{+}{ }^{+} \mathrm{CD} 4^{+}\right)$and $\mathrm{T}$ cytolytic $\left(\mathrm{CD} 3^{+} \mathrm{CD} 8^{+}\right)$lymphocytes and CD4/CD8 ratio.

\begin{tabular}{lrr}
\hline & Before race & \multicolumn{1}{c}{ After race } \\
\hline$\% \mathrm{CD}^{+} \mathrm{CD}^{+}$cells & $40.6 \pm 3.6$ & $42.9 \pm 5.5$ \\
$\% \mathrm{CD}^{+} \mathrm{CD}^{+}$cells & $10.6 \pm 5.8$ & $11.8 \pm 3.6$ \\
$\mathrm{CD} 4 / \mathrm{CD} 8$ ratio & $4.7 \pm 1.8$ & $3.9 \pm 1.2$ \\
\hline
\end{tabular}

Data are reported as means $\pm S D$. CD4/CD8 ratio represents the quotient between the percentage of $\mathrm{CD}^{+}{ }^{+} \mathrm{CD} 4^{+}$and $\mathrm{CD} 3^{+} \mathrm{CD} 8^{+}$ cells. The Student paired $t$-test was used for analyses.

between the proliferative response of lymphocytes after the race and the time to complete the race (Figure 3 ).

\section{Discussion}

We report the effect of an adventure sprint race on leukocytosis, lymphocyte proliferation and skeletal muscle damage of amateur runners. As expected, we observed a 2.3-fold increase in leukocyte number after the race, and also increased serum levels of AST, but not of ALT. Also, lymphocyte proliferative response to mitogenic stimulation was increased after the race.

Leukocytosis is the most consistent hematological alteration observed in response to prolonged exhaustive exercise, and the magnitude of change of the number of circulating leukocytes is proportional to the intensity and duration of the exercise. During long-duration exercise, leukocytosis primarily results from elevated granulocytes $(18,19)$, which are composed mainly of neutrophils. Consistently, in the present study racers experienced a 3.5-fold increase in neutrophils, and a 2-fold increase in monocytes following the race. Lymphocyte count, however, was not affected by the competition, nor was the frequency of $\mathrm{T}$ helper $\left(\mathrm{CD} 3^{+} \mathrm{CD}^{+}\right)$or $\mathrm{T}$ cytotoxic $\left(\mathrm{CD}^{+} \mathrm{CD}^{+}\right)$cells. To our knowledge, there have been no reports about exercise-induced leukocytosis following a sprint adventure race, but Davidson et al. (20) and Kratz et al. (21) also reported increased absolute numbers of neutrophils and monocytes, shortly after a marathon race (mean duration of $4 \mathrm{~h}$ and $30 \mathrm{~min}$ ), but not of circulating lymphocytes. However, Lucas et al. (22) observed increased numbers of circulating neutrophils (166\%),

Table 2. Adventure sprint race increased total leukocyte, neutrophil and monocyte but not lymphocyte counts.

\begin{tabular}{lcc}
\hline & Before race & After race \\
\hline Total leukocyte $\left(\times 10^{3}\right.$ cells $\left./ \mathrm{mm}^{3}\right)$ & $6.2 \pm 2.0$ & $14.8 \pm 3.5^{*}$ \\
Neutrophils $\left(\times 10^{3} \mathrm{cells} / \mathrm{mm}^{3}\right)$ & $3.5 \pm 1.6$ & $12.1 \pm 3.3^{*}$ \\
Monocytes $\left(\mathrm{cells} / \mathrm{mm}^{3}\right)$ & $200.0 \pm 100.0$ & $430.0 \pm 190.0^{*}$ \\
Lymphocytes $\left(\times 10^{3}\right.$ cells $\left./ \mathrm{mm}^{3}\right)$ & $2.2 \pm 0.5$ & $2.3 \pm 0.7$ \\
\hline
\end{tabular}

Data are reported as means $\pm S D$. ${ }^{*} \mathrm{P}<0.05$, compared to before race (Student paired $t$-test). 

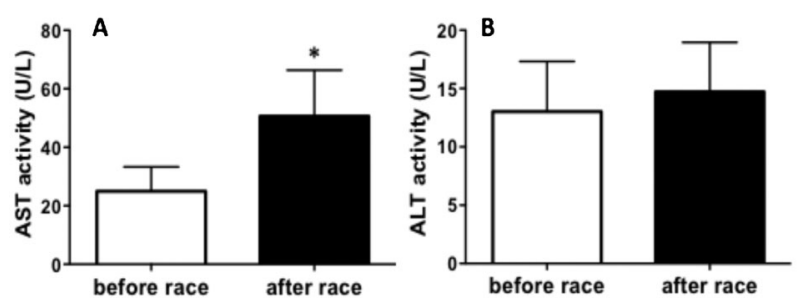

Figure 2. Plasma levels of AST $(A)$ but not of $A L T(B)$ were elevated after an adventure sprint race. Data are reported as means $\pm S D$. AST: aspartate amino transferase; ALT: alanine amino transferase. ${ }^{*} \mathrm{P}<0.05$, compared to before race (Student paired $t$-test).

lymphocytes (42\%) and monocytes (131\%) in the first part (15 to $30 \mathrm{~h}$ ) of a 411-km adventure race, a difference that can be attributed to the race duration.

It is generally assumed that leukocytosis after a race is mainly caused by the demargination of leukocytes induced by increased blood flow, although catecholamines and cortisol secreted during exercise may also contribute to leukocyte demargination (23-25). However, the observation of this and other studies of an increase in the absolute number of neutrophils and monocytes, but not of lymphocytes, argues that some of the leukocytosis observed in runners might be due to an inflammatory response caused by tissue injury (26). In an acute inflammatory response, neutrophils and monocytes are the first cells to reach the injured site, followed 24 to $48 \mathrm{~h}$ later by lymphocytes if tissue is not properly repaired. Consistent with this, we observed increased plasma levels of AST after the race that was positively correlated with leukocyte count. Others have also observed elevated AST levels in the blood of runners after a 21-km race (27) and after a marathon (21). Plasma elevation of AST and other intracellular proteins such as creatine kinase, lactate dehydrogenase and myoglobin, may indicate exertional rhabdomyolysis and leakage of proteins from skeletal muscle cells $(4,28)$, whereas ALT, a more specific marker for hepatic injury, showed little change in response to exercise. Since ALT, but not AST, was increased in the present study, plasma levels of ALT might be attributed mainly to leakage from muscle and not liver cells.

It has been suggested, mainly from epidemiological studies, that exhaustive exercise leads to a temporary immunosuppression, since athletes report more episodes of respiratory infections during periods of intense training and following competition $(7,29,30)$. In order to establish an effective adaptive immune response, lymphocytes must proliferate when stimulated by pathogens. Reduced lymphocyte proliferation following prolonged/exhaustive exercise, like marathons and triathlons, has been reported by many authors (31-33). Since an adventure sprint race is a high-demand competition (the aim is to reach as many checkpoints as possible within the allowed stage times, and in which competitors have to cover large

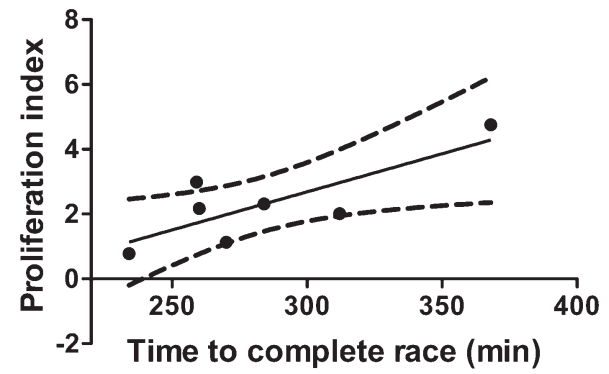

Figure 3. Correlation between lymphocyte proliferative response (proliferation index) and time to complete race. Data are reported as means $\pm S D$ (dotted lines).

distances as quickly as possible), the proliferative response of lymphocytes to PHA stimulation after the race was evaluated to address the potential immunosuppressive effect of the competition. To our surprise, PHA stimulation of the lymphocyte proliferative response was not reduced, but instead it was increased after the race. This suggests that this kind of competition may lead to temporary immunosuppression, but that it cannot be attributed to a reduced $\mathrm{T}$-cell proliferation response. It has been suggested that exhaustive competitions, like adventure races (11) and triathlons (34), increase lymphocyte death, thus compromising lymphocyte function, but $\mathrm{T}$ cell function was not evaluated in those reports.

The observed increased lymphocyte proliferative response indicates that factors produced and/or secreted during the race might be the mitogenic stimulus priming these cells. It is well known that prolonged exercise elicits the secretion of a series of soluble factors, like cytokines and hormones, many of which have potential lymphocyte priming activity. As reported by Radom-Aizik et al. (35), Jurkat cells, an immortalized T-cell line, have increased proliferative response to the stimulation by proliferating nuclear cell antigen when treated with serum obtained from healthy, young donors after $30 \mathrm{~min}$ of exercise. This indicates that serum factors present after exercise are able to modulate the proliferative response of lymphocytes in vitro. It can also be suggested that other factors released from damaged skeletal muscle cells, for example, can activate lymphocytes to engage in the inflammatory response to exercise. Heat shock proteins ( $\mathrm{Hsp}$ ) are a candidate factor, released from cells during exercise (36), capable of stimulating lymphocytes $(37,38)$. As demonstrated by Haug et al. (39), human Hsp70 complexed to antigenic peptides enhances activation and proliferation of human memory TCD4 ${ }^{+}$cells. Although we did not find a correlation between AST levels and the proliferative response of lymphocytes, increased AST levels reflect leakage of proteins from muscle, which may include Hsp, amongst others. A positive correlation between lymphocyte proliferative response and time to complete the race was observed, suggesting that the proliferative response of lymphocytes following the race 
was dependent on exercise intensity. Many potential lymphocyte-activating factors released during exercise are also induced in an intensity-dependent way, reinforcing the hypothesis that factors released during the race may be involved in lymphocyte activation, resulting in increased lymphocyte proliferative response. However, the identification of such factors, as well as their potential immunomodulatory action in response to exercise, has not yet been conducted.

In summary, this study showed that an adventure sprint race induced a strong leukocytosis, marked by increased numbers of circulating neutrophils and monocytes, which were correlated with plasma AST levels in response to long duration/exhaustive exercise, consistent with observations of other investigators. Contrary to the exercise-induced immunosuppression hypothesis, increased lymphocyte proliferative response was also induced by the competition. Compared with traditional or controlled long-duration exercise, adventure races impose a series of additional stresses to the athlete

\section{References}

1. Bruunsgaard $H$, Galbo $H$, Halkjaer-Kristensen J, Johansen TL, MacLean DA, Pedersen BK. Exercise-induced increase in serum interleukin-6 in humans is related to muscle damage. J Physiol 1997; 499 (Part 3): 833-841.

2. McCarthy DA, Dale MM. The leucocytosis of exercise. A review and model. Sports Med 1988; 6: 333-363, doi: 10.2165/00007256-198806060-00002.

3. Ostrowski K, Rohde T, Asp S, Schjerling P, Pedersen BK. Pro- and anti-inflammatory cytokine balance in strenuous exercise in humans. J Physiol 1999; 515 (Part 1): 287-291, doi: 10.1111/j.1469-7793.1999.287ad.x.

4. Siegel AJ, Silverman LM, Lopez RE. Creatine kinase elevations in marathon runners: relationship to training and competition. Yale J Biol Med 1980; 53: 275-279.

5. Bermon S. Airway inflammation and upper respiratory tract infection in athletes: is there a link? Exerc Immunol Rev 2007; 13: 6-14.

6. Konig D, Grathwohl D, Weinstock C, Northoff H, Berg A. Upper respiratory tract infection in athletes: influence of lifestyle, type of sport, training effort, and immunostimulant intake. Exerc Immunol Rev 2000; 6: 102-120.

7. Nieman DC. Exercise, upper respiratory tract infection, and the immune system. Med Sci Sports Exerc 1994; 26: 128139, doi: 10.1249/00005768-199402000-00002.

8. Mars M, Govender S, Weston A, Naicker V, Chuturgoon A. High intensity exercise: a cause of lymphocyte apoptosis? Biochem Biophys Res Commun 1998; 249: 366-370, doi: 10.1006/bbrc.1998.9156.

9. Adamson I. Runner's world guide to adventure racing: how to became a successful racer and adventure athlete. Rodale 200; $1-24$

10. Townes DA, Talbot TS, Wedmore IS, Billingsly R. Event medicine: injury and illness during an expedition-length adventure race. J Emerg Med 2004; 27: 161-165, doi: 10. 1016/j.jemermed.2004.02.018. during competition, which include environmental and soil conditions, nutritional and hydration strategies, amongst others. This race was conducted in a region of rugged terrain with great variation in altitude, characterized by high solar incidence and large variations in temperature and humidity. This imposed high physical, thermoregulatory and technical demands on the competitors, which undoubtedly contributed to the observed effects. Leukocytosis and increase of lymphocyte proliferative response might be due to soluble and/or cellular factors released in response to exercise, and may be involved in the regenerative inflammatory response to exercise.

\section{Acknowledgments}

Research supported by FAPEMIG (\#APQ-4263-5.01/ 07 and \#APQ-00581-11). The kits for determination of AST and ALT were kindly provided by Bioclin, Quibasa Química Básica, Brazil. The authors acknowledge the technical collaboration of the chemist Thyago José Silva.

11. Levada-Pires AC, Fonseca CE, Hatanaka E, Alba-Loureiro T, D'Angelo A, Velhote FB, et al. The effect of an adventure race on lymphocyte and neutrophil death. Eur J Appl Physiol 2010; 109: 447-453, doi: 10.1007/s00421-010-1363-4.

12. Jackson AS, Pollock ML. Generalized equations for predicting body density of men. 1978. Br J Nutr 2004; 91: 161-168.

13. Bicalho HM, Gontijo CM, Nogueira-Machado JA. A simple technique for simultaneous human leukocytes separation. J Immunol Methods 1981; 40: 115-116, doi: 10.1016/00221759(81)90087-9.

14. Openshaw P, Murphy EE, Hosken NA, Maino V, Davis K, Murphy $\mathrm{K}$, et al. Heterogeneity of intracellular cytokine synthesis at the single-cell level in polarized T helper 1 and T helper 2 populations. J Exp Med 1995; 182: 1357-1367, doi: 10.1084/jem.182.5.1357.

15. Tossige-Gomes R, Avelar NC, Simao AP, Neves CD, Brito-Melo GE, Coimbra CC, et al. Whole-body vibration decreases the proliferativeb response of TCD4 $(+)$ cells in elderly individuals with knee osteoarthritis. Braz J Med Biol Res 2012; 45: 1262-1268, doi: 10.1590/S0100-879X20120 07500139.

16. Lyons AB, Hasbold J, Hodgkin PD. Flow cytometric analysis of cell division history using dilution of carboxyfluorescein diacetate succinimidyl ester, a stably integrated fluorescent probe. Methods Cell Biol 2001; 63: 375-398, doi: 10.1016/ S0091-679X(01)63021-8.

17. Angulo R, Fulcher DA. Measurement of Candida-specific blastogenesis: comparison of carboxyfluorescein succinimidyl ester labelling of $\mathrm{T}$ cells, thymidine incorporation, and CD69 expression. Cytometry 1998; 34: 143-151, doi: 10.1002/(SICI)1097-0320(19980615)34:3<143::AIDCYTO4>3.0.CO;2-I.

18. Saxton JM, Claxton D, Winter E, Pockley AG. Peripheral blood leucocyte functional responses to acute eccentric 
exercise in humans are influenced by systemic stress, but not by exercise-induced muscle damage. Clin Sci 2003; 104: 69-77, doi: 10.1042/CS20020096.

19. Suzuki K, Nakaji S, Yamada M, Liu Q, Kurakake S, Okamura N, et al. Impact of a competitive marathon race on systemic cytokine and neutrophil responses. Med Sci Sports Exerc 2003; 35: 348-355, doi: 10.1249/01.MSS.000 0048861.57899 .04 .

20. Davidson RJ, Robertson JD, Galea G, Maughan RJ. Hematological changes associated with marathon running. Int J Sports Med 1987; 8: 19-25, doi: 10.1055/s-20081025634.

21. Kratz A, Lewandrowski KB, Siegel AJ, Chun KY, Flood JG, Van Cott EM, et al. Effect of marathon running on hematologic and biochemical laboratory parameters, including cardiac markers. Am J Clin Pathol 2002; 118: 856-863, doi: 10.1309/14TY-2TDJ-1X0Y-1V6V.

22. Lucas SJ, Anglem N, Roberts WS, Anson JG, Palmer CD, Walker RJ, et al. Intensity and physiological strain of competitive ultra-endurance exercise in humans. J Sports Sci 2008; 26: 477-489, doi: 10.1080/02640410701552872.

23. Foster NK, Martyn JB, Rangno RE, Hogg JC, Pardy RL. Leukocytosis of exercise: role of cardiac output and catecholamines. J Appl Physiol 1986; 61: 2218-2223.

24. Gader AM, Cash JD. The effect of adrenaline, noradrenaline, isoprenaline and salbutamol on the resting levels of white blood cells in man. Scand J Haematol 1975; 14: 5-10, doi: 10.1111/j.1600-0609.1975.tb00287.x.

25. Tvede N, Kappel M, Klarlund K, Duhn S, Halkjaer-Kristensen $\mathrm{J}$, Kjaer M, et al. Evidence that the effect of bicycle exercise on blood mononuclear cell proliferative responses and subsets is mediated by epinephrine. Int J Sports Med 1994; 15: 100-104, doi: 10.1055/s-2007-1021028.

26. Wells CL, Stern JR, Hecht LH. Hematological changes following a marathon race in male and female runners. Eur $\mathrm{J}$ Appl Physiol Occup Physiol 1982; 48: 41-49, doi: 10.1007/ BF00421163.

27. Lippi G, Schena F, Salvagno GL, Montagnana M, Gelati M, Tarperi $C$, et al. Acute variation of biochemical markers of muscle damage following a $21-\mathrm{km}$, half-marathon run. Scand J Clin Lab Invest 2008; 68: 667-672, doi: 10.1080/00 365510802126844.

28. Thompson GR. Hazards of running a marathon: creatine kinase MB can be raised without myocardial infarction. BMJ
1997; 314: 1023-1025, doi: 10.1136/bmj.314.7086.1023.

29. Nieman DC, Johanssen LM, Lee JW, Arabatzis K. Infectious episodes in runners before and after the Los Angeles Marathon. J Sports Med Phys Fitness 1990; 30: 316-328.

30. Peters EM, Bateman ED. Ultramarathon running and upper respiratory tract infections. An epidemiological survey. S Afr Med J 1983; 64: 582-584.

31. Eskola J, Ruuskanen O, Soppi E, Viljanen MK, Jarvinen M, Toivonen $\mathrm{H}$, et al. Effect of sport stress on lymphocyte transformation and antibody formation. Clin Exp Immunol 1978; 32: 339-345.

32. MacNeil B, Hoffman-Goetz L, Kendall A, Houston M, Arumugam $Y$. Lymphocyte proliferation responses after exercise in men: fitness, intensity, and duration effects. J Appl Physiol 1991; 70: 179-185.

33. Rohde T, MacLean DA, Hartkopp A, Pedersen BK. The immune system and serum glutamine during a triathlon. Eur J Appl Physiol Occup Physiol 1996; 74: 428-434, doi: 10.1007/BF02337723.

34. Levada-Pires AC, Cury-Boaventura MF, Gorjao R, Hirabara $\mathrm{SM}$, Puggina EF, Pellegrinotti IL, et al. Induction of lymphocyte death by short- and long-duration triathlon competitions. Med Sci Sports Exerc 2009; 41: 1896-1901, doi: 10.1249/MSS.0b013e3181a327a2.

35. Radom-Aizik S, Leu SY, Cooper DM, Zaldivar F Jr. Serum from exercising humans suppresses t-cell cytokine production. Cytokine 2007; 40: 75-81, doi: 10.1016/j.cyto.2007.08 008.

36. Lancaster GI, Febbraio MA. Mechanisms of stress-induced cellular HSP72 release: implications for exercise-induced increases in extracellular HSP72. Exerc Immunol Rev 2005; 11: 46-52.

37. Chen T, Cao X. Stress for maintaining memory: HSP70 as a mobile messenger for innate and adaptive immunity. Eur $\mathrm{J}$ Immunol 2010; 40: 1541-1544, doi: 10.1002/eji.201040616.

38. Figueiredo C, Wittmann M, Wang D, Dressel R, Seltsam A, Blasczyk R, et al. Heat shock protein 70 (HSP70) induces cytotoxicity of T-helper cells. Blood 2009; 113: 3008-3016, doi: 10.1182/blood-2008-06-162727.

39. Haug M, Dannecker L, Schepp CP, Kwok WW, Wernet D, Buckner JH, et al. The heat shock protein Hsp70 enhances antigen-specific proliferation of human CD4 + memory T cells. Eur J Immunol 2005; 35: 3163-3172, doi: 10.1002/ eji.200535050. 